\title{
Beta-thalassemia-X-linked thrombocytopenia syndrome
}

INSERM

\section{Source}

INSERM. (1999). Orphanet: an online rare disease and orphan drug data base. Betathalassemia-X-linked thrombocytopenia syndrome. ORPHA:231393

Beta-thalassemia - X-linked thrombocytopenia is a form of beta-thalassemia (see this term) characterized by splenomegaly and petechiae, moderate thrombocytopenia, prolonged bleeding time due to platelet dysfunction, reticulocytosis and mild betathalassemia. 